\title{
A CAMPER SHADE OF ROAR: RONALD FIRBANK'S CONCERNING THE ECCENTRICITIES OF CARDINAL PIRELLI AND IVY COMPTON-BURNETT'S PASTORS AND MASTERS
}

\author{
José María Díaz-Lage \\ Universidad Internacional de La Rioja
}

\begin{abstract}
This paper looks at some of the manifestations of camp in two very different novels from the 1920s: Ronald Firbank's Concerning the Eccentricities of Cardinal Pirelli and Ivy ComptonBurnett's Pastors and Masters. Emphasis is placed on those elements which derive from camp's detachment, theatricalization and fixation on the surface. Two specific aspects are examined in both novels: their use of dialogue (particularly its discontinuity) and their use of static, tableau-like plots. The final considerations address the relationship between camp and irony as seen in camp's rejection of moral judgement.

KeYwords: Ronald Firbank, Ivy Compton-Burnett, camp, detachment, dialogue, static plot.

\section{EL CAMP EN DOS NOVELAS DE LA DÉCADA DE LOS AÑOS VEINTE: CONCERNING THE ECCENTRICITIES OF CARDINAL PIRELLI, DE RONALD FIRBANK, Y PASTORS AND MASTERS, DE IVY COMPTON-BURNETT}

\section{RESUMEN}

El presente artículo analiza algunas de las manifestaciones del camp en dos novelas de la década de los ańos veinte muy diferentes entre sí: Concerning the Eccentricities of Cardinal Pirelli, de Ronald Firbank, y Pastors and Masters, de Ivy Compton-Burnett. Se presta especial atención a los elementos derivados de características del camp como el desapego, la teatralización y la insistencia en la superficie. Se examinan dos aspectos específicos en ambas novelas: su uso del diálogo (en particular su discontinuidad) y su uso de tramas estáticas similares a los cuadros teatrales. Las consideraciones finales abordan la relación entre el camp y la ironía tal y como se evidencian en el rechazo camp de los juicios morales. Palabras Clave: Ronald Firbank, Ivy Compton-Burnett, camp, desapego, diálogo, trama estática. 


\section{INTRODUCTION}

Whilst the novels of Ronald Firbank and Ivy Compton-Burnett are not the first texts that come to mind when we think of the Roaring Twenties, there is also a certain chronological incompatibility between the two authors: Firbank published some of his most important novels, such as Valmouth (1919), before the 1920s, whilst Compton-Burnett's best-known novels -for instance, More Women than Men (1933), A Family and a Fortune (1939) or Manservant and Maidservant (1947)were published much later. However, the texts with which we shall be concerned here do belong to the same period: thus, Compton-Burnett's Pastors and Masters appeared in 1925 and Firbank's Concerning the Eccentricities of Cardinal Pirelli was published in 1926, shortly after its author's death. The similarities between the two authors are not immediately obvious either. Both authors are inextricably bound in the bibliography on camp, starting with Susan Sontag's 1964 "Notes on 'Camp" (1996, 278). Admittedly, such a reduced canon will not allow us to reach wideranging conclusions, but it may provide an apt illustration of some manifestations of camp in the 1920s.

Following Sontag, I will be focusing on what she terms the essence of camp: "its love of the unnatural: of artifice and exaggeration" (275). Following Robert F. Kiernan, camp is here understood to "proliferate in all forms of art and behavior that offer the opportunity for a contrast between negligible content and elaborate form" (1990, 12); to return to Sontag's classic formulation, camp emphasizes "texture, sensuous surface, and style at the expense of content" (278). In this paper, camp is not read as a phenomenon pertaining exclusively to homosexual culture, although there is an undeniable connection between the two (see Clark 1993; Kiernan 1990, 16; Sontag 1996, 290). It should not be understood, despite the title of Kiernan's book, to be synonymous with frivolity, even though frivolity is an important component of camp: for instance, there is a sense in which the novels of ComptonBurnett are not frivolous at all. Rather, camp is "a frivolity unbound by conventional considerations of morality" (Kiernan 1990, 148). The detached way in which both of our authors deal with potentially indecorous situations is an eloquent example of this type of frivolity. For instance, Cardinal Pirelli famously opens with a scene in which the eponymous protagonist baptizes a dog: this is indicated, in the first paragraph of the novel, by the supremely aloof phrase "a christening- and not a child's" (Firbank 1950, 333).

Of all the distinguishing qualities of camp, the most relevant for this paper is its peculiar motionlessness: it is incompatible with many of the conventions of the realist novel, particularly with the notion of a character evolving. Sontag (1996) argues as follows:

What Camp taste responds to is "instant character" ... and, conversely, what it is not stirred by is the sense of the development of character. Character is understood as a state of continual incandescence- a person being one, very intense thing. This attitude toward character is a key element of the theatricalization of experience embodied in the Camp sensibility ... Wherever there is development of character, Camp is reduced. (286) 
Sontag's argument hints at an essential aspect of the texts that are discussed in this paper: if the camp sensibility renders character theatrical, it requires a spectator, as hinted by Scott Long (1989): "All the energies in the camp object are directed toward bringing such a moment in the consciousness that views it. More than almost any other aesthetic, camp thus turns continually outward. The camp moment is incomplete, it is not camp, without the satisfactory response from its audience" (55). A similar point is made by David Galef and Harold Galef (1991): "the presence of inhibition is crucial, just as the discharge onto an audience is an essential end-point. The camp practitioner needs an auditor; otherwise, he is like Berkeley's tree that falls in the forest with no one to hear it" (18).

These points, along with the view that camp is primarily, but not exclusively, a way of looking at things (Sontag 1996, 277, 279), lead us to the issue of intention. It is one thing to look at a phenomenon -say, to take one of Sontag's examples, old Flash Gordon comics (278) - from a camp perspective, so that we appreciate it in a frivolous, aesthetic and somewhat detached manner, and quite another for an artist to knowingly produce a work which is camp. Kiernan acknowledges that this is one of the central problems in any attempt to understand, let alone theorize, camp: "with the exception of Firbank, who knew he was camping, it is doubtful that the novelists discussed in these pages would happily hear themselves described as camps... Compton-Burnett thought of herself as a serious novelist" $(1990,149)$.

It is for this reason that this paper chooses to discuss Firbank, a novelist whose works are generally considered to be consciously, supremely camp, alongside Compton-Burnett, who is often (see Sontag 1996, Goldman 1999 -even though he refers to frivolity rather than to camp-, Hotz-Davies 2019, Kiernan 1990, Long 1989), but by no means unanimously, related to camp. Taken at face value, both novels are radically different; however, we are concerned with some of the similarities between them brought about by the presence of camp.

\section{CONVERSATION PIECES}

Both of our authors have in common a virtuosic reliance on dialogue. Pastors and Masters, specifically, excels at using dialogue to drive the narrative, to the extent that it is the main narrative resource. In Goldman's words, "voices float upwards from a murky, vague world" $(1999,296)$. Let us illustrate this procedure by means of a-necessarily long-extract from chapter IV, which describes the prize-giving fête at the school. Mr. Merry, the headmaster, has just been talking to his wife. With no narratorial intervention or any other type of transition, he is suddenly interacting with a different set of characters, some of whom have not been introduced yet:

"Well, Mr. Merry," said another father. "And what have you to say for those two boys of mine?"

"Ah, the little fellows! My wife, she has a soft spot in her heart for them."

"And how do they do at their books? John is a scatterbrain, I am afraid. I suppose these long holidays nowadays are a good thing?" 
“Ah, little John! Well, some boys haven't the brains to scatter. And all work and no play, you know!"

"He would not like to be called little John," said a grown-up sister, who was with the father.

"Wouldn't he?" said Emily. "Not when we only keep them until they are fourteen! But the young are cruel."

"Ah, Miss Herrick, you will talk in your way to us," said Mr. Merry. "You know Miss Basden, do you not, Mr. Bentley?"

"No, I think not," said Mr. Bentley, simply.

"Why, she is always here, Father. Every year," said the daughter. "How are you, Miss Basden?"

"She is always here. Every year here with us," said Mr. Merry, lifting his hands on and off Miss Basden's shoulders. "Always here, so that people don't notice her any more than they do one of ourselves. Because she is one of ourselves, if she will be, aren't you, Miss Basden?” (67-68)

This exchange is carrying out a fairly complex narrative function: first of all, it provides an implicit dramatis persone that is not alluded to in any other way; thus, we know that the conversation takes place between, in this order, Mr. Merry, Mr. Bentley, Miss Bentley, Miss Herrick and Miss Basden (who does not intervene). This is a frequent technique of Compton-Burnett, perceptively described by Mary McCarthy (1969): "one by one, the characters at the table materialize in a ghostly way, like lights turning on. Until they gave tongue, you did not know they were there; their place on the stage was dark" (121).

Secondly, the conversation establishes a distinction between the characters who are associated to the school and those who are not. The former-Mr. Merry, Miss Herrick and Miss Basden- have all appeared in previous chapters; the latter -Mr. Bentley and Miss Bentley-appear here for the first time, Delia Bentley being as yet unnamed, and will subsequently be the protagonists of chapter $\mathrm{V}$.

Thirdly, and most importantly, subtle characterization is taking place. The reader will not fail to recognize Mr. Merry's evasiveness - often represented by the interjection "ah"- which here, as it normally does, resorts to trite sentimentality ("my wife, she has a soft spot in her heart for them") and flattering cliché ("some boys haven't the brains to scatter"). Emily Herrick's penchant for abrupt, epigrammatic, frequently discomfiting wit ("but the young are cruel") is also in evidence.

Mr. Bentley is immediately portrayed as one of Compton-Burnett's family tyrants (see Hardy 2016, 13; Kiernan 1990, 126; McCarthy 1969, 121) through the way he refers to his sons: "what have you to say for [rather than "about"] those two boys of mine?" Unfoiled by Mr. Merry's unctuousness, he single-mindedly pursues his train of thought: "how do they do at their books? John is a scatterbrain, I am afraid." His immediate allusion to long school holidays introduces the fact that $\mathrm{Mr}$. Bentley quite dislikes the company of his sons, as he explicitly states in chapter V.

In many of Compton-Burnett's novels, her characters have an unnerving way of saying the unspeakable: "the sort of thing that is generally thought unsayable - the sort of thing that belongs to unconscious awareness inasmuch as it seems anterior to the censoring function of the superego" (Kiernan 1990, 129). This is truer of other 
novels than of Pastors and Masters, where the dialogue is comparatively mild. The acerbic wit of Emily Herrick can often verge on the cynical: "I thought it mattered about Mr. Merry's not being educated, as we were having him for a schoolmaster" (1952, 26); but no character utters words that we might consider unspeakable.

What is present in Pastors and Masters, however, is Compton-Burnett's ability to suggest the inner thoughts of her characters by means of their lines of dialogue: in Goldman's cogent formulation, her dialogue "functions to depict the process of character thought" $(1999,297)$. To take just one example:

"I have been a long fool, idle through seventy years of a good life," said Herrick. "But I don't know that I can wish that about Crabbe. I feel as if I should not have written this book, apart from his death; as if it would not have shaped itself in my mind as I now feel it. Of course there is no connection. None at all. None. But it came to me, as I sat there, the whole thing, the whole book. There it was. I can't explain it". (Compton-Burnett 1952, 30).

Readers might not be able to guess from this paragraph that Herrick did not write his book but stole it from the dying Crabbe; but they certainly realize that Herrick is lying and -via the masterly sequence "no connection. None at all. None"that there is some sort of unsavoury link between his sudden plan for a book and Crabbe's death. Herrick's assertion "I can't explain it" ostensibly means "I find no explanation for it," but readers come to realize that the assertion also means "I am not to explain it." Much later in the novel, when this link is revealed, albeit just to some characters, Herrick's thought process is rendered in a similar way as he realizes that the book he stole did not belong to a dead man (Crabbe) but to a living one (Bumpus) who will not fail to notice the theft: "Old Crabbe's room? That night he died?" said Herrick. "Did you leave your book in the room, did you say, Bumpus? Ah, yes, it was a sad night, that, for us. Good old Crabbe! I always wondered that he never wrote. I have often said it. Did you leave your book in the room, did you say, Bumpus?" (Compton-Burnett 1952, 92).

In other cases, Compton-Burnett is able to evoke a character's thought even where there is no speech. This is the case of a scene in chapter V where Mr. Bentley is reproaching one of his sons for not inviting his school friends to his home:

"It does not look as if you had no friends to ask to your home, as always seems to be the case, when I ask you why you do not bring them here ... Anyone would think you would be proud to let them see your father and your sister and your surroundings. I can't think what makes you so affected and self-conscious about it. Now, once for all, what is it?"

"Well, do not speak, then, do not speak ... Go away, then, and do not speak. Behave as my children always do. Go away, without a word, to your own concerns." (88)

Again, it is plain to readers what the child's unspoken reply would have been. The empty space between his father's two interventions makes it clear: it is the domestic tyrant himself who makes his children so self-conscious and reluctant to bring their friends home. This is a trait that McCarthy (1969) highlights: "you can 
follow what [the characters] are thinking as plainly as if they said it aloud, which often they dare not do" (123).

Even though his narrators are more likely than Compton-Burnett's to explain a character's thoughts, Firbank has a similar talent for suggesting things that are not spoken aloud. This talent, however, is at the service of a very different aesthetic project: Firbank's dialogue is not designed to portray the character's thought processes but a complex series of allusions, double entendres and risqué meanings. The most salient formal feature of his dialogue is its discontinuity: "his characters' thoughts about morality do not even reach syntactical completion as a rule" (Kiernan 1990, 62). Let us consider an excerpt from chapter $V$, which presents a conversation between Conca, Marchioness of Macarnudo, and Luiza, Duchess of Sarmento:

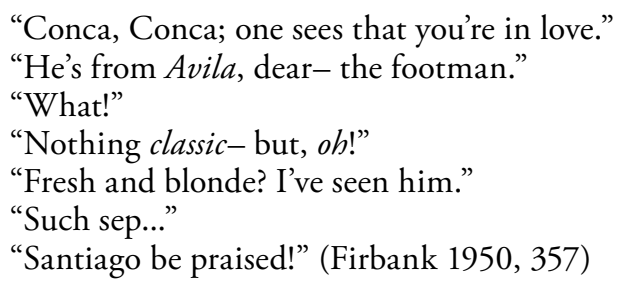

It is probably idle to try to decide for which word the truncated "sep" stands: not even the most conscientious of Firbank scholars, Brigid Brophy, attempted to do so. In keeping with Firbank's frequent allusions to the language of flowers (see Brophy 1973, 341-90), the word might be "sepal"; in keeping with the "pæan to her husband's '...” (Firbank 1950, 361) written by Diana Beira Baixa, it might be "septer" or some such archaism. It is more productive to focus on Firbank's use of italics in this fragment. Firbank often engages in a very specific use of italics: "italics are another signal of frivolity's non-signifying nature ... Italics in Firbank's novels stress the failure of highlighted words to contain anything extraordinary, instead emphasizing the word as word" (Goldman 1999, 293). That is the case, to a certain extent, in the extract above, but at the same time the italicized words indicate that they are more meaningful than they seem at first glance although, crucially, the referent of the allusion is unavailable. Thus with "Avila": the footman's place of origin is signalled as significant but there is no way for readers to understand why or how. Likewise, it is impossible to ascertain exactly what "classic" means in the context of this conversation.

Both of these instances suggest a shared code between the interlocutors, who have known each other for a very long time, "since the summer the sun melted the church bells and their rakish, pleasure-loving, affectionate hearts had dissolved together. But this had not been yesterday, no; for the Marchioness was a grandmother now" (Firbank 1950, 357). The conversation between the two ladies is overheard by Mother Saint-Mary-of-the-Angels, who is moving around the party at the DunEden palace: the eavesdropper is not privy to the full significance of what she hears, and neither is the reader. In his everyday life Firbank was, according to Brophy, "a collector and connoisseur of overheard remarks either non-understandable (because the context was unknown) or open to misunderstanding" $(1973,426)$. This ability 
is deployed in his writings to such an extent that it merits Brophy's description of him as "a virtuoso of the overheard" (426).

The italicized "oh!" is probably the clearest instance: there is little doubt that the Duchess is aware of the full meaning of the exclamation - the narrator is probably aware, too- but it remains outside the grasp of the nun and the reader. It is a remarkable trait of Firbank's technique that he can make such elliptical dialogue so evocative.

A similar use of dialogue can be found in chapter VII, between two pupils of the College of Noble Damosels:

"You can tell that by his eyebrows!" a girl of thirteen, and just beginning as a woman, remarked.

"Que barbaridad."

"Last summer at Santander Maria-Manuela and I bathed with him, and one morning there was a tremendous sea, with terrific waves, and we noticed unmistakably". (370)

Italics are put to different uses here. "Que barbaridad" merely signals a different language being used, whilst "terrific" is a straightforward case of italics being used for emphasis. It is "that" which displays a relevant use of italics: as in the previous extract, the reader -again an eavesdropper- has no way of knowing what "that" is. Italics act as another of Firbank's graphic indicators that the unspoken is unspeakable, as described by Kristiaan P. Aercke: "Firbank's phrases that may or may not be puns, his exclamation marks, rows of dots, gaps and pauses solicit the reader to yoke together semantic connotations that legalized verbal definitions and conventional, hierarchical syntactic flow try to keep apart" $(1995,174)$. What adds to the mischievousness of this formal strategy is the fact that the unspoken might well be considered comparatively innocent.

\section{EXTERNALITIES}

The discontinuities and hidden depths in Firbank's and Compton-Burnett's dialogues are a paradoxical manifestation of camp's concern with surfaces and its rejection of realist narrative techniques that suggest a sense of profundity. Amongst other such manifestations we may number the tendency to develop action by means of tableaux. Both of the novels under scrutiny here present scenes and chapters which are notably static.

Firbank's novels are located in what Aercke simply -and cogently- calls "Firbankland" $(1995,169)$. In Cardinal Pirelli the setting is Clemenza, "in white Andalucia" (Firbank 1950, 342). Although it seems specific, this location is essentially a vaguer Southern European, Catholic, Romance-language territory, as seen in the composite nature of its toponyms and anthroponyms, which not only relate it to Spain (Calle de la Pasión, Cartuja, Amalia Bermudez, Santander, Rambla, Lake Orense), but also to Italy (Clemenza, Pirelli) and Portugal (Diana Beira Baixa, Madame Always Alemtejo, Duchess-Dowager of Vizeu).

Settings are mostly circumscribed to Clemenza, including the cathedral (the sacristy, the church itself and several adjoining areas), the archiepiscopal palace 
(including its garden), the DunEden palace and the College of Noble Damosels. Chapter IV constitutes an exception in that it is not set in Andalusia but in a Vatican loggia; chapter VIII is located at the Monastery of the Desierto. As befits a connoisseur such as Firbank, references to artists and their works are more specific and they contribute to the setting of the novel much more than geographical details do: amongst many others, they include paintings by Valdés Leal (1950,343), Ribera (345) and El Greco $(396,405)$ in the cathedral, "a dozen old Zurbarans" in the monastery of the Desierto (382) and works by Murillo (357), Winterhalter and Isabey (359) in the DunEden palace.

The way in which each of the chapters of Cardinal Pirelli changes the setting of the previous one makes one think of Firbank's first method of plot arrangement: at least in the earlier stages of his career, he wrote "phrases on long strips of paper" (Brophy 1973, 69) which he then arranged in the appropriate order. Describing this technique, William Lane Clark (1993) points out that "plot structure in Firbank's work consequently develops mechanically, rather than organically, from the interrelated arrangement of discrete elements instead of through causal linear progression" (141). This is a very apposite observation, except for two details: first, Clark seems to suggest that all of Firbank's novels were composed following this method, which does not seem to have been the case (see Brophy 1973, 173). Second, the notions of organic and mechanic form to which Clark is alluding can be traced to Samuel Taylor Coleridge's lectures on Shakespeare: "the form is mechanic, when on any given material we impress a pre-determined form, not necessarily arising out of the properties of the material ... The organic form, on the other hand, is innate, it shapes, as it developes [sic], itself from within" (Coleridge 1937, 46; see also Fletcher 1970, 15-19). However, not even those novels which adhere to the conventions of realism develop in a truly organic manner. They resort to a number of textual strategies that give an impression of organicism: in Peter Bürger's apt formulation, "the organic work of art seeks to make unrecognizable the fact that it has been made" $(1999,72)$. Such works strive to suggest organic development- but they are, in actual truth, as completely artificial as Firbank's novels.

The description of Firbank's plots as following a mechanical development is most appropriate, but it must be understood as a deliberate choice which is a central part of his aesthetic: "it is an aspect of Firbank's modernism that the reader is always conscious of the disciplines of realism playing no role in the narrative" (Kiernan 1990, 63). Artifice is always foregrounded in Firbank: writing about his use of images, Brophy (1973) argues that "These he does not dispose as if they were building-blocks, squarely one on top of the other, in the expected continuities of narrative, argument or exposition, where so much is put in merely for the sake of the narrative's, argument's or exposition's thread and an impression of solidity is built up by the cheat of the writer's telling the reader a great many things the reader could supply for himself" (69).

Firbank's deliberate avoidance of realism poses the question of where to locate his artistic practice. Of course, this paper reads Cardinal Pirelli as a camp novel; but, as Kiernan $(1990,148)$ suggests, camp is too elusive -and too dependent on the reader's response- to be thought of as an independent genre or a tradition. Barbara Hardy argues that Firbank's genre-like Compton-Burnett's, Henry James's and Thomas Love 
Peacock's- is the conversation novel (2016, 28, 39; Peacock, Firbank and ComptonBurnett are also grouped by King et al. [1979] and by Kiernan [1990]). Plausible as this view is, the conversation novel seems to me as elusive a notion as the camp novel and just as hard to be conceptualized as a genre (see, for instance, Thomas 2012).

Don Adams's choice is to read Firbank as a practitioner of the pastoral: this is an interesting approach, but it is not without problems. It is, I believe, absolutely correct to argue that "we have traditionally looked for a novel's argument in its narrative progress ... Firbank's narratives progress in an almost arbitrary manner, in which reliance on plot is reduced to a minimum" (Adams 2009, 75), but I find it difficult to acquiesce with the view that "the aspects of Firbank's novels that are most confusing and off-putting to contemporary readers and critics are pastoral in nature" (77). On the contrary, it seems to me that those aspects are related to camp -which does not play a significant role in Adams's reading of Firbank, except for a passing comment (92) - rather than to an alleged "pure pastoralism" (82).

The view that Firbank should be considered a modernist seems to me more tenable. Several critics, including Adams himself (2009, 75), Kiernan $(1990,50)$, Brophy $(1973,97-8)$-to a certain extent- and Mahoney (2020), have made this point. I have argued elsewhere (Díaz 2012) that there is a strand of Anglo-American modernism which, far from delving in the inner thoughts of its characters, presents them externally and, as it were, mechanically; and which, instead of the usual emphasis on symbolism, resorts to allegory to articulate its narrative practice. Although this issue is beyond the scope of the present paper, I believe that there are significant coincidences between this strand of modernism and the novels of Firbank.

The locations in Pastors and Masters are much more limited than those in Cardinal Pirelli. The action takes place in and around a boys' school in an unnamed "old university town" (Compton-Burnett 1952, 13). The settings comprise the different areas of the school (mainly indoors, with a few references to school grounds), three homes (the Herricks', the Fletchers' and the Bentleys') and, just as an aside, a set of college rooms. Compton-Burnett's "astonishingly concise, encapsulated, staccato prose" (King et al. 1979, 132) would not easily tolerate the same types of allusion that Firbank so deftly includes; and her aesthetic is incompatible with such a wealth of detail.

However, despite its very different use of location, Compton-Burnett's novel displays a similar development of plot as a series of plateaux. Settings in the novel are just backgrounds for conversation and, insofar as there is action, it consists of a series of changes in setting. The clearest example is the way in which school rooms are repurposed to serve different functions. After the prize-giving function, which has thrown the usual room arrangements into disarray, Emily Herrick comments that this is the appropriate moment to ask the Bentleys to dinner: "this room has to be regarded as the drawing-room, and a classroom made into the dining-room, and the boys' basement dining-room suppressed, to have anything at all. And Mrs. Merry can't be asked to do that often" (Compton-Burnett 1952, 71). Mr. Merry, for one, resents this change: "all this pretending that we do not live as we do, but in different rooms, and in a different way, as if the ordinary way did not make work enough!" (107). He is not aware, and neither is the reader, that Emily Herrick is there whilst he 
gives vent to his frustration. Once again, Compton-Burnett displays in real time, so to speak, his embarrassed realization that this is the case, symbolized by two dashes:

"A second rate kind of thing, I call it, for all of us to be doing. And it isn't as if Miss Herrick will not give us away, so that all of it is as good as nothing - Ah, Miss Herrick! Ah, I did not see you, Miss Herrick. We were just saying how you would give us away, you know, and talk as you will to us, so that our guests would see through all our little changes. Ah, Miss Herrick, you and I both have our way of talking, haven't we?" (107-108)

Emily Herrick's reply is, as usual, detached and biting, although it is not too clear whether the use of the adverb "honestly" is her irony or the author's: after all, the school's practice seems to be unencumbered by honesty. Mr. Herrick, proprietor of the school and its nominal head, devotes ten minutes a day to school matters and is keener on stealing the book that a dead man wrote; Mr. Merry, headmaster, does not have a degree but is quite resourceful in the areas of hypocrisy and minor deceit: "Yes, I am sure we have everything due to us. And it is so suitable for you not to like the second rate. But I am afraid the basement dining-room is that. I believe Mr. Bentley would think so. We ought to be going to the study, which is the drawing-room tonight. We have honestly left that as it is" (108).

It is not infrequent for critics to resort to theatrical metaphors when discussing Compton-Burnett's novels: for instance, McCarthy (1969) refers to her "stage directions" (113), the "stichomythia" in which her characters engage (114), the "lights turning on" and the characters" "place in the stage" (121). The changes in room arrangement can be added to this list: they are, as it were, stage changes effected from the flies by a number of hands, the servants, anonymous but for Fanny. The limited cast of characters move between those different stages with very few mentions of motion: rather than go from one locale to the next, they often seem to remain in the same place whilst the locales themselves change.

Furthermore, the characters of both novels display an element of performance that is entirely in keeping with camp's need for an audience: for instance, in Compton-Burnett's, after histrionically scolding his son, Mr. Bentley "went upstairs and stood by himself, repeating his speech with additions which had not occurred to him" $(1952,83)$. And in Firbank's, shortly before his death, "dispossessed of everything but his fabulous mitre", Cardinal Pirelli addresses an invisible audience, "some phantom image in the air" and announces, "as you can perfectly see, I have nothing but myself to declare" (1950, 405; as pointed out by Brophy [1973, 566], this is a Wildean echo). These examples lead us, one more time, to camp as a sensibility that relies on "the theatricalization of experience" (Sontag 1996, 287).

\section{CODA}

"Frivolous", "superficial" and "camp" still possess pejorative implications that brand a work as minor, the usual assumption being that major works are not superficial but deep, not frivolous but positively earnest. Those implications do not 
apply to these novels: they are never simply droll, although they are, each in their way, very funny. Their breezy detachment is in itself a refusal to judge characters and their actions, however questionable or deplorable they might be: both authors have in common, as Hardy $(2016,10)$ says of Compton-Burnett, a soft spot towards their characters. This affection is, in turn, very closely related to the amoral nature of camp laughter (see Kiernan 1990, 16-7), which is devoid of satire's inherent moral intent.

This is not to say that camp and irony are incompatible, and in this sense Sontag's view that pure examples of camp "are dead serious" $(1996,282)$ is overly reductionist; she qualifies this view later in her essay when she argues that "Camp is playful, anti-serious ... One can be serious about the frivolous, frivolous about the serious" (288). Rather, the amorality that Kiernan identifies as the main feature of camp imposes a type of irony that must be unrelated to the "morally correct laughter" of satire $(1990,16)$.

It is in all likelihood pointless to dwell upon whether camp's attention to the surface stems from the absence of moral intent or, on the contrary, the refusal to peer into the unseen depths of characters and their motivations leads to the abandonment of the moralizing purpose. Camp, in the words of Sontag, "proposes a comic version of the world. But not a bitter or polemical comedy. If tragedy is an experience of hyperinvolvement, comedy is an experience of underinvolvement, of detachment" (1990, 288). Whatever must be revealed about the inner world of the characters can be displayed externally and aloofly.

It is a critical cliché to use the terms "subversive" or "transgressive" as the ultimate seal of approval, and yet these terms constantly spring to one's mind when trying to summarize the appeal of these novels. The features that I have tried to describe are best seen as instances of refusal, as Adams points out about Firbank: "Firbank's refusal to delve below the surface of his character's words and actions in search of motives and complexes is a refusal to play the game of essentials that is at the heart of the modern mania with uncovering the truth of sexuality. For Firbank, appearance is essence" $(2009,86)$. Such refusal is every bit as challenging as those manifestations of early-twentieth-century narrative which purport to fathom the hidden psychological depths of their characters, even when those depths reveal themselves to be lack-lustre: Compton-Burnett's ability to allude to inner turmoil by means of "ellipsis, circularity and non sequitur" (Goldman 1999, 298) is a case in point. The forms of discontinuity that I have been trying to describe, be they in truncated, unanswered or overheard dialogue or in the mechanical presentation of plot in the shape of tableaux ought not to be seen as subordinate to more realistic narrative modes -and even less as evidence of artistic failure- but as specimens of a different and highly sophisticated approach to some of the same concerns that those modes address. 


\section{WORKS CITED}

Adams, Don. 2009. Alternative Paradigms of Literary Realism. London: Palgrave Macmillan.

Aercke, Kristiaan P. 1995. “Ronald A. Firbank: 'Fragrant Prayers, a Fury of Pain'.” In The Turn of the Century: Modernism and Modernity in Literature and the Arts, edited by Christian Berg, Frank Durieux \& Geert Lernout, 165-183. Berlin and New York: De Gruyter.

Brophy, Brigid. 1973. Prancing Novelist: A Defence of Fiction in the Form of a Critical Biography in Praise of Ronald Firbank. New York: Barnes and Noble.

Bürger, Peter. 1999. Theory of the Avant-Garde. Translated by Michael Shaw. Minneapolis: University of Minnesota Press.

Clark, William Lane. 1993. "Degenerate Personality: Deviant Sexuality and Race in Ronald Firbank's Novels." In Camp Grounds. Style and Homosexuality, edited by David Bergman, 134-155. Amherst: University of Massachusetts Press.

Coleridge, Samuel Taylor. 1937. Essays and Lectures on Shakespeare. London: J.M. Dent \& Sons.

Compton-Burnett, Ivy. (1925) 1952. Pastors and Masters. London: Victor Gollancz.

DíAz, José María. 2012. "Allegory and Fragmentation in Wyndham Lewis's The Wild Body and Djuna Barnes's A Book." In Modernism, Postmodernism, and the Short Story in English, edited by Jorge Sacido, 47-76. Amsterdam and New York: Rodopi.

Firbank, Ronald. (1926) 1950. Concerning the Eccentricities of Cardinal Pirelli. In Five Novels by Ronald Firbank. New York: New Directions.

Fletcher, Angus. 1970. Allegory. The Theory of a Symbolic Mode. Ithaca: Cornell University Press.

Galef, David \& Harold Galef. 1991. “What Was Camp.” Studies in Popular Culture 13 no. 2: 11-25.

Goldman, Jonathan. 1999. "The Parrotic Voice of the Frivolous: Fiction by Ronald Firbank, I. Compton-Burnett, and Max Beerbohm." Narrative 7 no. 3: 289-306.

Hardy, Barbara. 2016. Ivy Compton-Burnett. Edinburgh: Edinburgh University Press.

Hotz-Davies, Ingrid. 2019. “The Jewel in the Gutter: Camp and the Incorporation of Dirt.” In The Dark Side of Camp Aesthetics: Queer Economies of Dirt, Dust and Patina, edited by Ingrid Hotz-Davies, Georg Vogt and Franziska Bergmann, 15-25. London: Routledge.

Kiernan, Robert F. 1990. Frivolity Unbound: Six Masters of the Camp Novel, Thomas Love Peacock, Max Beerbohm, Ronald Firbank, E.F. Benson, P.G. Wodehouse, Ivy Compton-Burnett. London: Continuum.

KING, Francis, et al. 1979. “Major/Minor: A Symposium.” In Ivy Compton-Burnett, special issue of Twentieth Century Literature 25 no. 2: 127-134.

Long, Scott. 1989. "Useful Laughter: Camp and Seriousness." Southwest Review 74 no. 1: 53-70.

Mahoney, Kristin. 2020. “Camp Modernism and Decadence.” In Decadence: A Literary History, edited by Alex Murray, 341-360. Cambridge: Cambridge University Press.

McCarthy, Mary. 1969. "The Inventions of I. Compton-Burnett." In The Writing on the Wall and Other Literary Essays, 111-140. Harmondsworth: Penguin Books.

Sontag, Susan. (1966) 1996. "Notes on 'Camp'” In Against Interpretation and Other Essays, 275292. New York: Picador.

Thомаs, Bronwen. 2012. Fictional Dialogue: Speech and Conversation in the Modern and Postmodern Novel. Lincoln: University of Nebraska Press. 